\title{
THE EXCRETION OF -MALIC ACID IN RELATION TO THE TRICARBOXYLIC ACID CYCLE IN THE KIDNEY*
}

\author{
By P. VISHWAKARMA $\dagger$ AND W. D. LOTSPEICH
} (From the Department of Physiology, University of Cincinnati College of Medicine,
Cincinnati, Ohio)

(Submitted for publication May 27, 1958; accepted October 16, 1958)

The tricarboxylic acid cycle, described by Krebs and Johnson (1), has become generally accepted as the final common pathway for the aerobic oxidation of carbohydrate, fat and protein in most tissues of a large number of animal species. For reference during the discussion that follows, this cycle is presented in its usual schematic form in Figure 1.

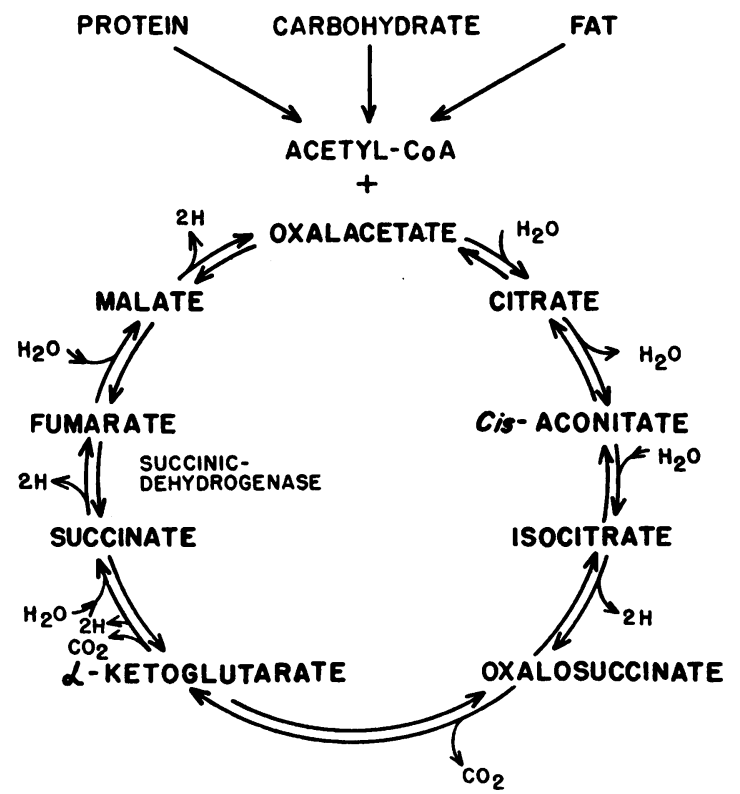

Fig. 1. Diagrammatic Representation of the Tricarboxylic Acid Cycle

This sequence of biological oxidations is present in mammalian kidney, and all of its intermediate organic acid substrates have been identified at one time or another in urine of lower animals and man (2). Under certain circumstances

* This work was supported by grants (A-1381) from the National Institutes of Health, United States Public Health Service, and the American Heart Association and the Youngstown Area Heart Association.

$\dagger$ Research Fellow in Physiology, on leave from State Medical Service of Bihar, India. the excretion of some of these acids shows remarkable variations. For instance, in metabolic alkalosis the rate of excretion of citrate and to a lesser extent of $\alpha$-ketoglutarate is greatly elevated (3-6). On the other hand, in metabolic acidosis, or more precisely in conditions favoring intracellular acidosis such as potassium deficiency $(4,5)$ or the administration of Diamox ${ }^{\circledR}(7)$, the rate of excretion of these same acids is reduced almost to zero.

The way in which fluctuating acid-base balance causes these changes in organic acid excretion is not certain. However, a large body of indirect evidence supports the concept that some of these acids, besides undergoing glomerular filtration and tubular reabsorption, are produced in the renal tubular cells and secreted into the urine. It is supposed that it is this tubular synthesis that is sensitive to $\mathrm{pH}$ changes within the cells and thus affects the changing rates of organic acid excretion. Such would appear to be the case for citrate and $\alpha$-ketoglutarate although direct evidence for their tubular secretion is not available. In the case of malic acid, however, such evidence is available and constitutes the main subject of the present paper.

In 1953 Craig, Miller, Owens and Woodward reported (8) that during the intravenous infusion of sodium salts of either $\alpha$-ketoglutaric or succinic acids in dogs there was both glomerular filtration and net tubular secretion of malic acid. Under these circumstances they found that the infusion of malonic acid, the succinoxidase inhibitor, caused an abrupt change in the pattern of malic acid excretion to one of glomerular filtration with net tubular reabsorption.

It is the purpose of the present paper to report experiments on malic acid excretion in the dog that confirm and extend these findings of Craig and co-workers and include a description of the varying patterns of malic acid excretion during 
infusion of a number of the other cycle acids including fumarate and $l$-malate itself. These results will then be discussed in relation to the general problem of organic acid excretion and the biochemical function of the tricarboxylic acid cycle in the kidney.

\section{METHODS}

The experiments were performed on unanesthetized, hydrated female mongrel dogs trained to lie on an animal table while loosely restrained. Sodium salts of the acids of the tricarboxylic acid cycle were administered by constant intravenous infusion. Standard clearance techniques were used to quantify the rates of glomerular filtration and urinary excretion of the several acids studied. The creatinine clearance was used as a measure of glo- merular filtration rate by methods described previously (9). Intravenous infusions were administered at a constant rate of $3 \mathrm{ml}$. per minute. Malic acid was determined essentially by the method of Hummel (10) which gave excellent quantitative malate recoveries from both plasma and urine, even in the presence of considerable amounts of each of the other cycle substrates. Succinate in tungstic acid filtrates of plasma and in diluted urines was determined enzymatically after ether extraction according to the method described by Umbreit, Burris and Stauffer (11). Citrate was measured with slight modification according to Natelson, Pincus and Lugovoy (12). Malate was found to be completely filtrable from plasma over a wide range of concentrations. The ultrafiltration studies were carried out first with Visking cellophane bags in air. The results of these studies were compared and found to agree with those from dialysis against phosphate buffer as described by Taggart (13).

TABLE I

Experiment illustrating pattern of $l$-malic acid excretion and effect of malonate during infusion of sodium citrate in dog

\begin{tabular}{|c|c|c|c|c|c|c|}
\hline \multirow{2}{*}{$\begin{array}{l}\text { Total } \\
\text { concurrent } \\
\text { time }\end{array}$} & \multirow{2}{*}{$\begin{array}{l}\text { Glomerular } \\
\text { filtration } \\
\text { rate }\end{array}$} & \multicolumn{5}{|c|}{ b-Malic acid } \\
\hline & & Plasma & Filtered & Excreted & Secreted & Reabsorbed \\
\hline $\min$. & $\begin{array}{l}\text { ml./min. } \\
\text { Prime-Sodium citr } \\
\text { Infuse-Sodium citr }\end{array}$ & $\begin{array}{l}\mu \mathrm{gg} \cdot / \mathrm{ml} . \\
/ \mathrm{Kg} \cdot+ \\
\mathrm{Kg} \cdot / \mathrm{mi}\end{array}$ & $\begin{array}{l}\text { mg./min. } \\
\text { tinine, } 0 \\
0.9 \% \mathrm{~N}\end{array}$ & $\begin{array}{l}\text { mg./min. } \\
\text { Gm./Kg. } \\
\text { + creatin }\end{array}$ & $\begin{array}{l}\mu g . / \mathrm{min} . \\
1.8 \mathrm{mg} .\end{array}$ & $\begin{array}{l}\mu \mathrm{g} . / \mathrm{min} . \\
\mathrm{g} . / \mathrm{min} \text {. }\end{array}$ \\
\hline \multirow[t]{2}{*}{$\begin{array}{l}30-40 \\
40-50 \\
50-60\end{array}$} & $\begin{array}{l}110.0 \\
113.4 \\
119.2\end{array}$ & $\begin{array}{l}3.37 \\
3.37 \\
3.13\end{array}$ & $\begin{array}{l}375 \\
383 \\
373\end{array}$ & $\begin{array}{l}925 \\
900 \\
825\end{array}$ & $\begin{array}{l}554 \\
517 \\
452\end{array}$ & \\
\hline & \multicolumn{6}{|c|}{$\begin{array}{l}\text { Prime-Disodium malonate, } 0.41 \mathrm{Gm} . / \mathrm{Kg} . \\
\text { Infuse-As before + malonate, } 1.26 \mathrm{mg} . / \mathrm{Kg} . / \mathrm{min} .\end{array}$} \\
\hline $\begin{array}{r}90-100 \\
100-110\end{array}$ & $\begin{array}{l}114.6 \\
101.4\end{array}$ & $\begin{array}{l}3.63 \\
3.50\end{array}$ & $\begin{array}{l}416 \\
355\end{array}$ & $\begin{array}{l}288 \\
250\end{array}$ & & $\begin{array}{l}128 \\
105\end{array}$ \\
\hline
\end{tabular}

TABLE II

Experiment illustrating pattern of l-malic acid excretion and effect of malonate during infusion of sodium a-ketoglutarate in dog

\begin{tabular}{|c|c|c|c|c|c|c|}
\hline \multirow{2}{*}{$\begin{array}{l}\text { Total } \\
\text { concurrent } \\
\text { time }\end{array}$} & \multirow{2}{*}{$\begin{array}{l}\text { Glomerular } \\
\text { filtration } \\
\text { rate }\end{array}$} & \multicolumn{5}{|c|}{$l$-Malic acid } \\
\hline & & Plasma & Filtered & Excreted & Secreted & Reabsorbed \\
\hline $\min$. & \multicolumn{6}{|c|}{$\begin{array}{l}\text { ml./min. } \\
\text { Prime- } \alpha \text {-ketoglutaric acid, } 0.49 \mathrm{Gm} . / \mathrm{Kg} . \text { (neutralized with } \mathrm{NaOH})+ \text { creatinine, } \\
\begin{array}{l}0.15 \mathrm{Gm} . / \mathrm{Kg} . \\
\text { Infuse- } \alpha \text {-ketoglutaric acid, } 6.7 \mathrm{mg} . / \mathrm{Kg} . / \mathrm{min} . \text { (neutralized with } \mathrm{NaOH} \text { ) + creati- } \\
\text { nine, } 1.9 \mathrm{mg} . / \mathrm{Kg} . / \mathrm{min} . \mathrm{in} 0.9 \% \mathrm{NaCl}\end{array}\end{array}$} \\
\hline \multirow[t]{2}{*}{$\begin{array}{l}30-40 \\
40-50 \\
50-60\end{array}$} & $\begin{array}{l}78.0 \\
82.5 \\
86.5\end{array}$ & $\begin{array}{l}17.8 \\
18.6 \\
19.2\end{array}$ & $\begin{array}{l}1.39 \\
1.53 \\
1.66\end{array}$ & $\begin{array}{l}3.32 \\
3.23 \\
2.68\end{array}$ & $\begin{array}{l}1.93 \\
1.70 \\
1.02\end{array}$ & \\
\hline & \multicolumn{6}{|c|}{$\begin{array}{l}\text { Prime-Disodium malonate, } 0.41 \mathrm{Gm} . / \mathrm{Kg} . \\
\text { Infuse-As before + malonate, } 4.00 \mathrm{mg} . / \mathrm{Kg} . / \mathrm{min} \text {. }\end{array}$} \\
\hline $\begin{array}{r}90-100 \\
100-110 \\
110-120\end{array}$ & $\begin{array}{l}75.0 \\
78.0 \\
72.8\end{array}$ & $\begin{array}{l}16.5 \\
15.1 \\
13.8\end{array}$ & $\begin{array}{l}1.24 \\
1.18 \\
1.01\end{array}$ & $\begin{array}{l}0.92 \\
0.86 \\
0.68\end{array}$ & & $\begin{array}{l}0.32 \\
0.32 \\
0.33\end{array}$ \\
\hline
\end{tabular}


RESULTS

The pattern of malate excretion during infusion of citrate, $\alpha$-ketoglutarate, or succinate

Table I shows the details of an experiment illustrating the pattern of $l$-malate excretion during the infusion of sodium citrate. Because of its toxicity when infused at high rates, citrate administration had to be limited. Nevertheless it is seen that its infusion produced a small but definite elevation in plasma malate concentration to some 3.0 to $3.4 \mu \mathrm{g}$. per $\mathrm{ml}$.; endogenous malate levels vary from 0.5 to $2 \mu \mathrm{g}$. per ml. Furthermore, in the first three periods malate excretion was some $500 \mu \mathrm{g}$. per minute greater than its filtration, indicating that a rather large tubular secretion of malate occurred during citrate infusion even in these relatively small amounts.

Effect of malonate. Since the secretion of malate here must depend first on its synthesis from citrate via the tricarboxylic acid cycle steps shown in Figure 1, it would be expected that malonic acid, the succinoxidase inhibitor, would block this part of the malate excretory process. Indeed, this is what happened. The high rate of tubular malate secretion seen in the first three periods disappeared after malonate and there appeared instead a net tubular reabsorption of malate amounting to 128 to $105 \mu \mathrm{g}$. per minute (last three periods). Thus there appears to be, as Craig and associates found, a bidirectional movement of malate across the renal tubule in the dog; the re- absorptive limb of the process becomes evident when the net tubular secretion is blocked after malonate (8).

Experiments similar in design to that shown in Table I were performed with $\alpha$-ketoglutarate and succinate. We wished to see whether the pattern of malate excretion seen with citrate was also observed during infusion of these two substrates which would likewise have to utilize the succinoxidase system in order to give rise to malate. Results of experiments of this type are shown with $\alpha$-ketoglutarate in Table II and succinate in Table III. It is apparent in both these experiments that the pattern of malate excretion during either $\alpha$-ketoglutarate or succinate infusion is qualitatively similar to that seen when citrate was substrate. Plasma malate is elevated as, consequently, is its rate of glomerular filtration. There is a large net tubular secretion which in each case is changed to a net tubular reabsorption after the addition of malonate to the infusion.

With $\alpha$-ketoglutarate and succinate there are, however, striking quantitative differences in malate excretion from that seen with citrate. For instance, with $\alpha$-ketoglutarate and even more so with succinate, plasma malate levels as well as rates of tubular secretion and tubular reabsorption (after malonate) are considerably higher than with citrate. Whether the increasing size of these functions with the three substrates bears any relation to their progressive nearness to succinoxidase in the cycle is a possibility but not one sub-

TABLE III

Experiment illustrating pattern of l-malic acid excretion and effect of malonate during infusion of sodium succinate in dog

\begin{tabular}{|c|c|c|c|c|c|c|}
\hline \multirow{2}{*}{$\begin{array}{c}\text { Total } \\
\text { concurrent } \\
\text { time }\end{array}$} & \multirow{2}{*}{$\begin{array}{l}\text { Glomerular } \\
\text { filtration } \\
\text { rate }\end{array}$} & \multicolumn{5}{|c|}{ l-Malic acid } \\
\hline & & Plasma & Filtered & Excreted & Secreted & Reabsorbed \\
\hline $\min$. & $\begin{array}{l}\text { ml. } / m i n . \\
\text { Prime-Succinic acid, } 0.56 \mathrm{Gm} . / \mathrm{K} \\
\text { Infuse-Succinic acid, } 5.1 \mathrm{mg} . / \mathrm{K} \\
\mathrm{Kg} . / \mathrm{min} . \text { in } 0.9 \% \mathrm{NaCl}\end{array}$ & $\begin{array}{l}\mu g . / m l . \\
\text { Kg. (neut } \\
g . / \mathrm{min} .\end{array}$ & $\begin{array}{l}\text { mg./min. } \\
\text { zed with } \\
\text { tralized }\end{array}$ & $\begin{array}{l}\text { mg./min. } \\
\mathrm{H})+\mathrm{cr} \\
\mathrm{NaOH})\end{array}$ & $\begin{array}{l}\text { mg./min. } \\
\text { nine, } 0.08 \\
\text { creatinine }\end{array}$ & $\begin{array}{l}\text { mg./min. } \\
.7 \mathrm{mg} . / \mathrm{Kg}\end{array}$ \\
\hline \multirow[t]{2}{*}{$\begin{array}{l}30-40 \\
40-50 \\
50-60\end{array}$} & $\begin{array}{r}101.5 \\
104.0 \\
99.0\end{array}$ & $\begin{array}{l}33.6 \\
31.2 \\
39.0\end{array}$ & $\begin{array}{l}3.41 \\
3.25 \\
3.86\end{array}$ & $\begin{array}{l}6.61 \\
8.26 \\
8.26\end{array}$ & $\begin{array}{l}3.20 \\
5.01 \\
4.40\end{array}$ & \\
\hline & $\begin{array}{l}\text { Prime-Disodium malonate, } 0.4 \\
\text { Infuse-As before }+ \text { malonate, }\end{array}$ & $\begin{array}{l}\mathrm{Gm} . / \mathrm{I} \\
.8 \mathrm{mg} . /\end{array}$ & in. & & & \\
\hline $\begin{array}{r}90-100 \\
100-110 \\
110-120\end{array}$ & $\begin{array}{l}75.0 \\
76.0 \\
73.8\end{array}$ & $\begin{array}{l}38.4 \\
30.0 \\
34.8\end{array}$ & $\begin{array}{l}2.88 \\
2.92 \\
2.57\end{array}$ & $\begin{array}{l}1.29 \\
1.50 \\
1.41\end{array}$ & & $\begin{array}{l}1.59 \\
0.79 \\
1.16\end{array}$ \\
\hline
\end{tabular}


TABLE IV

Experiments on the same dog showing higher rate of malate reabsorption during fumarate than during l-malate infusion

\begin{tabular}{|c|c|c|c|c|c|}
\hline \multirow{2}{*}{$\begin{array}{l}\text { Total } \\
\text { concurrent } \\
\text { time }\end{array}$} & \multirow{2}{*}{$\begin{array}{l}\text { Glomerular } \\
\text { filtration } \\
\text { rate }\end{array}$} & \multicolumn{4}{|c|}{ l-Malic acid } \\
\hline & & Plasma & Filtered & Excreted & Reabsorbed \\
\hline \multicolumn{6}{|c|}{ No. 20 fumarate infusion } \\
\hline \multicolumn{6}{|c|}{$\begin{array}{l}\text { Prime-Sodium fumarate, } 0.19 \mathrm{Gm} . / \mathrm{Kg} .+ \text { creatinine, } 0.15 \mathrm{Gm} . / \mathrm{Kg} . \\
\text { Infuse-Sodium fumarate, } 1.8 \mathrm{mg} . / \mathrm{Kg} . / \mathrm{min} .+ \text { creatinine, } 1.8 \mathrm{mg} . / \mathrm{Kg} . / \mathrm{min} \text {. in } 0.9 \% \mathrm{NaCl}\end{array}$} \\
\hline $\begin{array}{l}30-40 \\
40-50 \\
50-60\end{array}$ & $\begin{array}{l}111.6 \\
111.4 \\
109.0\end{array}$ & $\begin{array}{l}0.336 \\
0.331 \\
0.327\end{array}$ & $\begin{array}{l}37.5 \\
36.9 \\
35.7\end{array}$ & $\begin{array}{l}7.92 \\
9.00 \\
9.00\end{array}$ & $\begin{array}{l}29.6 \\
27.9 \\
26.7\end{array}$ \\
\hline
\end{tabular}

No. 21 malate infusion

Prime-Sodium $l$-malate, $0.15 \mathrm{Gm} . / \mathrm{Kg}$. + creatinine, $0.15 \mathrm{Gm} . / \mathrm{Kg}$.

Infuse-Sodium $l$-malate, $1.36 \mathrm{mg} . / \mathrm{Kg} . / \mathrm{min}$. + creatinine, $1.8 \mathrm{mg} . / \mathrm{Kg} . / \mathrm{min}$. in $0.9 \% \mathrm{NaCl}$

$\begin{array}{llllll}30-40 & 93.0 & 0.420 & 39.0 & 35.0 & 4.0 \\ 40-50 & 93.4 & 0.390 & 36.5 & 30.4 & 6.1 \\ 50-60 & 98.3 & 0.336 & 33.0 & 27.1 & 5.9\end{array}$

ject to proof from these data. The relative smallness of the malate parameters during citrate infusion is most likely related to the fact that its cardiac toxicity limits the amount that can be given.

The experiments presented thus far are in complete agreement with the results of Craig and coworkers (8) and confirm their finding of a bidirectional malate movement in the tubule of the dog kidney, and extend that finding to include citrate as well as $\alpha$-ketoglutarate and succinate as malate precursors in this phenomenon.

\section{The pattern of malate excretion during infusion of fumarate or l-malate}

It next became of interest to study the nature of malate excretion during infusion of substrates lying beyond the malonate-sensitive succinoxidase system in the cycle. Experiments were performed with two of these: fumarate and $l$-malate itself.

In the first experiment (No. 20) shown in Table IV sodium fumarate was given. This produced a marked elevation in plasma malate and, hence, in its glomerular filtration. In striking contrast to the earlier studies almost all the filtered malate was reabsorbed; no net tubular secretion was seen. In addition, the rate of tubular reabsorption of malate was much greater than that observed during malonate infusion with either citrate, $\alpha$-ketoglutarate, or succinate.

In the second experiment (No. 21) shown in Table IV sodium $l$-malate was infused in sufficient amounts to achieve plasma levels and filtered loads analogous to those achieved in the fumarate infusion studies. One can see that with malate infusion, as with fumarate, there was likewise glomerular filtration and net tubular reabsorption of malate; no tubular secretion was seen. However, in striking contrast to the fumarate experiment, the reabsorptive rate of malate was much lower, being only 4 to $6 \mathrm{mg}$. per minute, compared to 27 to $29 \mathrm{mg}$. per minute at analogous malate loads during fumarate infusion.

Experiments like No. 21, Table II, were repeated and rates of malate filtration, excretion and reabsorption during $l$-malate infusion were measured over a wide range of plasma malate levels. The massed data of six such experiments are presented in Figure 2. Although the curves were drawn through the points by inspection, it is apparent that below filtered loads of 4 to 5 $\mathrm{mg}$. per minute reabsorption of filtered malate is essentially complete. However, as plasma level rises a maximum reabsorptive rate ( $\mathrm{Tm}$ malate) is reached and remains relatively constant over a wide range of filtered malate loads. Thus in exhibiting a "Tm" (during $l$-malate infusion), the 


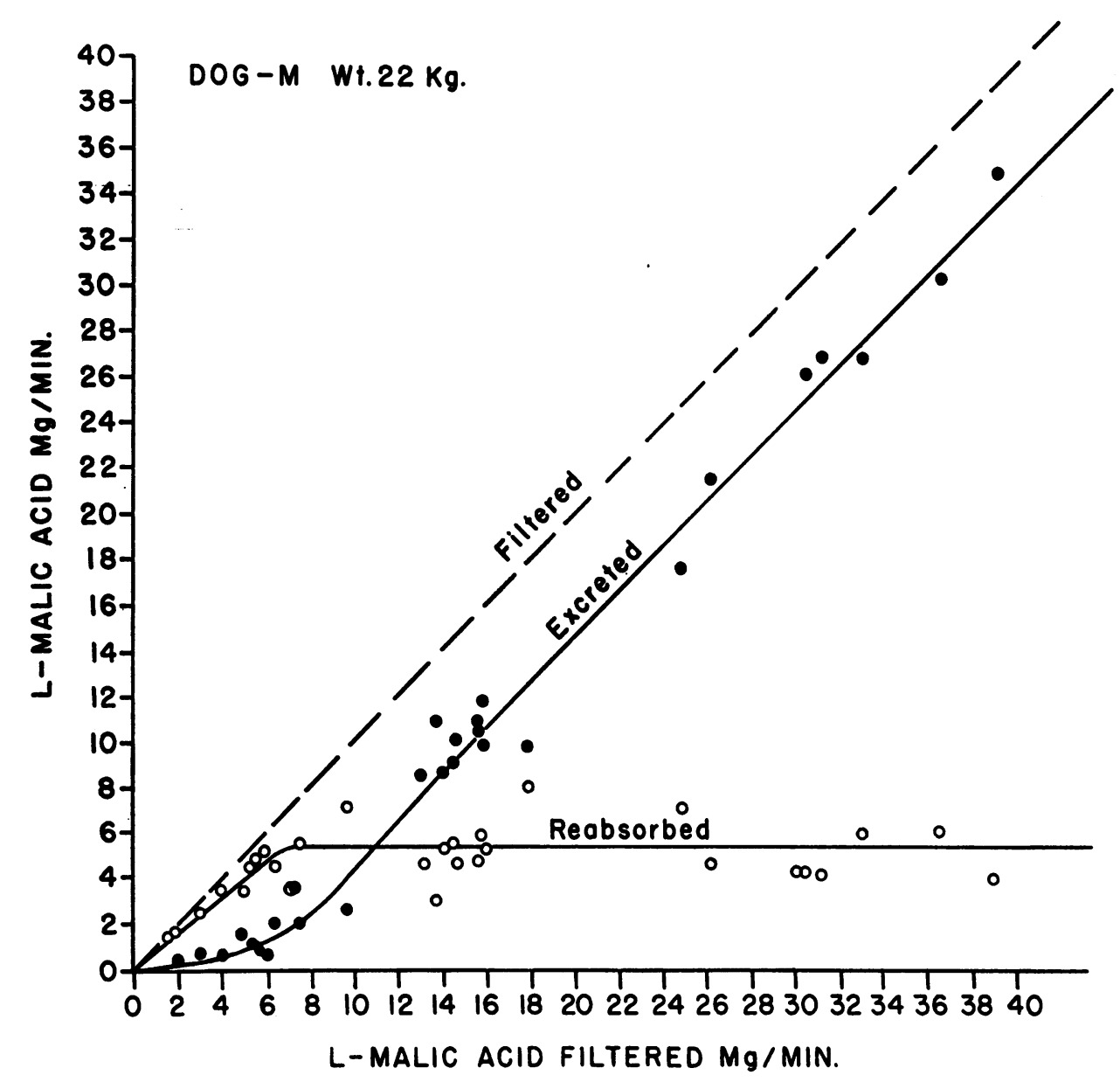

Fig. 2. Excretion and Reabsorption of Malate in Relation to Filtered Malate Load

malate reabsorptive mechanism resembles those of glucose, phosphate, sulfate and some amino acids.

\section{Catalytic effect of fumarate on malate reabsorption}

As was noted above in the experiments of Table $\mathrm{IV}$, the rate of malate reabsorption during fumarate infusion is some five to six times higher than it is with equivalent malate loads during sodium $l$-malate infusion. In attempting to design further experiments to clarify the nature of this difference. we were reminded of the catalytic "sparking" effect of fumarate in isolated tissues oxidizing pyruvate $(14,15)$. We wondered whether fumarate could exert a similar catalytic effect on malate reabsorption by "sparking" the oxidative energy production in the renal tubular cells.

To test this hypothesis, experiments such as that presented in Figure 3 were performed. So- dium $l$-malate was infused at rates similar to those in Experiment No. 21, Table IV. Analogous filtered loads of malate were reached, and, as is seen in the first two bars in the bottom set, the malate reabsorptive rate was also similar at about $4 \mathrm{mg}$. per minute. Now while maintaining this malate infusion constant, sodium fumarate, in onesixtieth the molar amount of infused malate, was added to the infusion and two more clearance periods were taken. With the fumarate addition the rate of malate reabsorption doubled or tripled as can be seen in the second two bars of the lower set. The massed data of two additional and similar experiments are presented in Figure 4. In each of these, two control periods were followed by four periods with fumarate addition. The black dots show malate reabsorption during control periods; these group around the dashed line representing $\mathrm{Tm}$ malate taken from Figure 2. 


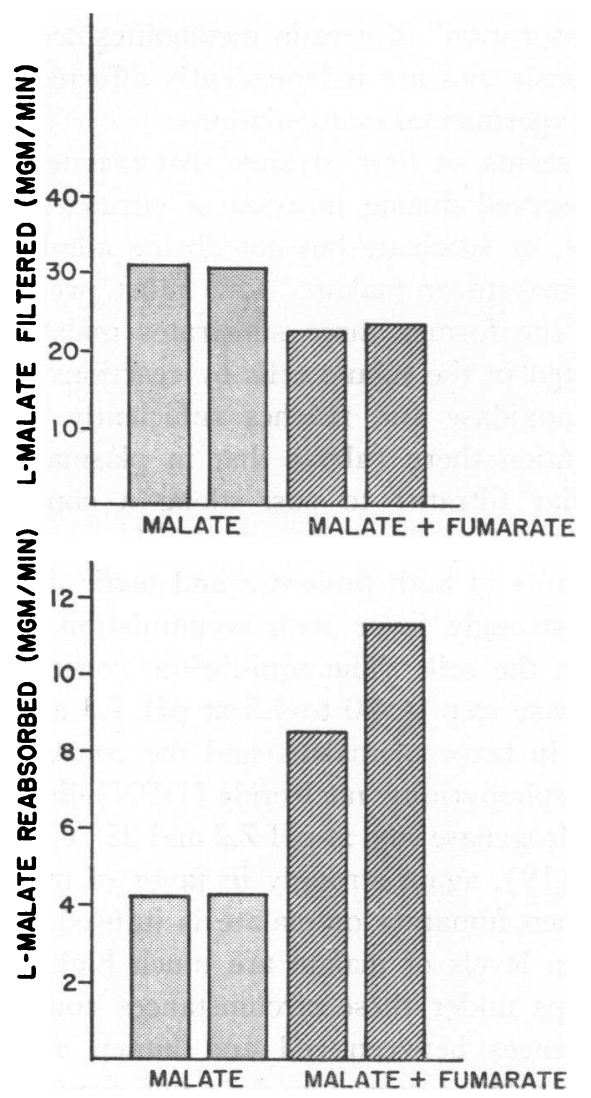

Fig. 3. An Experiment Illustrating the Catalytic Effect of Fumarate on Malate Reabsorption

The open circles represent rates of malate reabsorption during fumarate addition. In all cases malate reabsorptive rates were significantly higher during periods when fumarate was infused along with the malate.

The word "catalytic" to describe this effect of fumarate is used advisedly because these quantities of fumarate, of themselves, would never lead to malate loads or reabsorptive rates such as these. In addition, the effect is the more striking because it occurs with an actual decline in the filtered malate load (Figure 3 ), the result of a general reduction of plasma malate seen during the infusion of small doses of fumarate with $l$-malate.

\section{DISCUSSION}

The experiments presented here support the theoretical conclusion that the tricarboxylic acid cycle is involved in the tubular synthesis and secretion of malic acid, as well as in its reabsorption

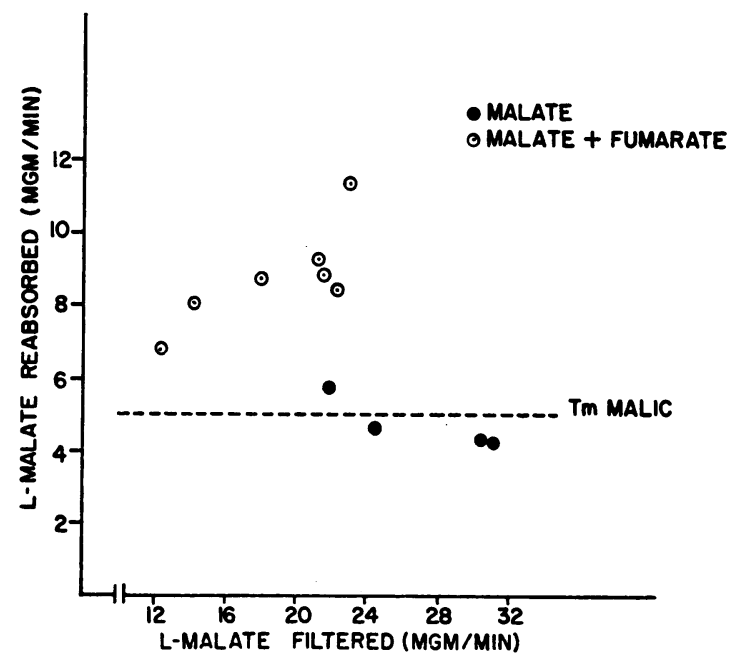

Fig. 4. Massed Data of Two Experiments Showing Effect of Fumarate on Malate Reabsorption

from the glomerular filtrate. These relations as visualized at present are summarized schematically in Figure 5. The upper tubular cell represents the mechanisms of malate reabsorption and the lower one, those of malate synthesis and secretion. Plasma malate level rises with infusion of citrate, $\alpha$-ketoglutarate, succinate, fumarate, and, of course, $l$-malate itself. The malate formed from these several substrates in various tissues, or administered preformed, is freely filtrable and passes into the glo-

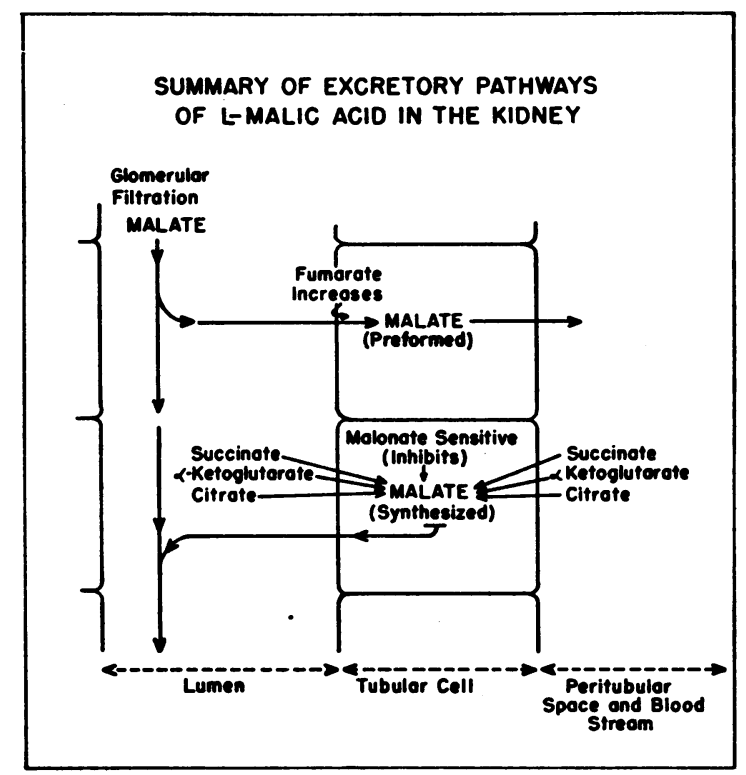

Fig. 5. Summary of the Pathways of Malate ExCRETION IN THE KIDNEY 
merular filtrate where it undergoes tubular reabsorption (upper cell). This mechanism exhibits a Tm during infusion of $l$-malate. It is unaffected by malonate. Catalytic amounts of fumarate accelerate the reabsorptive capacity of the tubules for malate some two- to threefold, and during the infusion of fumarate alone, malate reabsorption is five or six times as high as it is at equivalent loads during malate infusion. Substrates of the cycle such as citrate, $\alpha$-ketoglutarate and succinate get into the tubular cell (possibly from both sides as shown in the lower cell) and are synthesized there into malate by a malonate-sensitive mechanism presumably involving the succinoxidase system. That citrate and $\alpha$-ketoglutarate can gain entrance to the tubule cell from the lumen is known from the fact that tubular reabsorption of each acid has been observed $(16,17)$. These observations on the several mechanisms of malic acid excretion in the kidney raise several important points about the nature of the phenomena themselves and their relation to the larger problem of organic acid excretion, its function in the overall economy of the body, and the role of the tricarboxylic acid cycle in renal tubular function.

In measuring "reabsorption" or "secretion" by the clearance technique, one simply measures net difference between rate of glomerular filtration and urinary excretion of a substance. This measurement does not reveal multidirectional fluxes that may comprise the "net" movement, nor does it reveal the fate of a substance reabsorbed or secreted by the tubules. Thus with a metabolite such as malic acid the measurement of its "reabsorption" does not tell us whether it has been moved intact without utilization from glomerular filtrate to peritubular blood or whether it has been partly or completely "utilized" by the tubule cells. Therefore, the catalytic effect of fumarate on malate reabsorption could represent either a facilitation of its actual transtubular movement, an acceleration of its tubular "utilization," or both. To differentiate these possibilities, studies will be required in which one measures simultaneously excretion of malate by clearance techniques and its utilization by renal arteriovenous sampling. Although such studies have not appeared for malate, Cohen (17) has reported them for other metabolites: lactate, acetoacetate, pyruvate and $\alpha$-ketoglutarate. These studies have clearly shown that renal "utilization" and "reabsorption" of certain metabolites occur simultaneously and are independently affected by various experimental manipulations.

It seems, at first, strange that malate secretion is observed during infusion of citrate, $\alpha$-ketoglutarate, or succinate but not during administration of fumarate or malate. One must presume that with the former three substrates malate is synthesized in the tubule cells by reactions involving succinoxidase and reaches sufficiently high concentration there (above that in plasma and glomerular filtrate) to pass along a concentration gradient into luminal urine. The equilibrium constants of both fumarase and malic dehydrogenase strongly favor such accumulation of malate within the cell. The equilibrium constant of the fumarase step is 4.0 to 4.5 at $\mathrm{pH} 7.3$ and $25^{\circ} \mathrm{C}$. (18) in favor of malate, and the constant of the diphosphopyridine nucleotide (DPN)-linked malic dehydrogenase step at $\mathrm{pH} 7.2$ and $22^{\circ} \mathrm{C}$. is $2.33 \times$ $10^{-5}(19)$, again strongly in favor of malate.

When fumarate or malate is infused, however, plasma levels of malate are much higher. Thus perhaps under these circumstances concentration differences between cell and lumen are not so great, tubular secretion does not occur, and the reabsorptive limb of the bidirectional malate system becomes predominant. Whether this explanation of the observed facts is correct must await further study, but at the moment it seems a plausible formulation.

During infusion of citrate and $\alpha$-ketoglutarate, glomerular filtration and net tubular reabsorption of these acids have been observed $(16,17)$. Preliminary studies in our laboratory with succinate have produced succinate to creatinine clearance ratios varying from 0.78 to 1.25 , indicating that this acid is probably excreted predominantly by glomerular filtration when it is infused in the normal dog.

In contrast, however, the pattern of excretion of citrate and $\alpha$-ketoglutarate is different when other intermediates of the tricarboxylic acid cycle are infused or when acid-base balance is altered. And, as with malate, the evidence, although indirect, supports the concept that they are synthesized from precursors in the tubule cells and secreted into the urine. For instance, in 1937 Orten and Smith (20) showed in dogs that the infusion of succinate, malate, malonate, or maleate 
causes a remarkable increase in citrate excretion. A year later Krebs, Salvin and Johnson (21) reported similar studies with the rabbit and rat and explained Orten and Smith's results in terms of the "citric acid cycle" which by then had been clearly formulated in Kreb's laboratory. Krebs and coworkers (21) also explained Orten and Smith's malonate effect on the basis of its succinoxidase inhibition: citrate simply accumulated behind the block in the cycle and appeared in large quantities in the urine. Furthermore, in the malonate-treated animal, succinate, the plasma level of which was markedly increased, appeared in large quantities in the urine. In the case of citrate and $\alpha$-ketoglutarate, however, their increased rate of excretion was not accompanied by any change in their plasma levels. Thus the evidence indicated that tubular synthesis of citrate and $\alpha$-ketoglutarate from the injected precursors must have occurred, just as we have visualized it occurring during the secretion of malate in the experiments reported in the present paper. Abundant confirmation of the observations of Orten and Smith (20) and Krebs, Salvin and Johnson (21) is presented in the recent comprehensive paper by Nordmann and Nordmann (2).

All these studies make it appear likely that citrate, $\alpha$-ketoglutarate, fumarate, malate and oxaloacetate excretion during infusion of one of these acids occurs variously by combined processes of glomerular filtration and tubular secretion. Reabsorption may also be occurring, as with malate, but the net process appears to be tubular secretion under these circumstances. Only in the case of malate, in the study of Craig and associates (8) and the present one, has such a mechanism been shown experimentally. Similar studies with these other members of the tricarboxylic acid cycle are in progress.

It would appear that the organic aciduria of metabolic and respiratory alkalosis is also the result of tubular synthesis and secretion of citrate and $\alpha$-ketoglutarate. Milne, Scribner and Crawford (22) recently reported an observation strongly supporting this concept. They found that the increased citrate excretion of rats given potassium bicarbonate was associated with a considerable rise in renal tissue citrate; in fact, they reported citrate levels comparable to those seen in kidney tissue after fluoroacetate poisoning. One would visualize the synthesis of citrate and $\alpha$-ketoglutarate (and thus their urinary excretion) as being regulated primarily by intracellular $\mathrm{pH}$. This in turn would be a function of potassium concentration and associated intracellular bicarbonate (23). Organic acid excretion would thus become a function of $\mathrm{pH}$ in the tubule cells rather than of urinary $\mathrm{pH}$ or general changes in acid-base balance of the body.

In support of this idea is the fact that the "condensing enzyme" in tissues shows an equilibrium state much more in favor of citrate production as $\mathrm{pH}$ rises (19). Evans, MacIntyre, MacPherson and Milne (4) have shown that citrate and $\alpha$-ketoglutarate excretion rises in potassiumdepleted man given potassium chloride even in the face of a falling urinary $\mathrm{pH}$. And Orten and Smith (20) as well as Cooke and co-workers (5) have stressed the independence of organic aciduria and urinary $\mathrm{pH}$. In like manner both the tubular reabsorption and secretion of malate, in the present studies, appear to be independent of urinary $\mathrm{pH}$ and bicarbonate excretion. For example, in one experiment during the infusion of sodium $l$-malate, urine $\mathrm{pH}$ gradually rose from 7.30 to 7.81 and the rate of bicarbonate excretion, from 86 to $182 \mu \mathrm{M}$ per minute. But malate reabsorption remained relatively constant at 3.50 to $5.30 \mathrm{mg}$. per minute. Similar independence of malate secretion rate during succinate infusion has been observed.

The functions of organic acid excretion in relation to overall body economy are not completely clear. Cooke and associates (5) have suggested that organic acids may be secreted by the tubules and function as part of a fixed anion (chloride) conserving mechanism in alkalosis analogous to the fixed cation conservation mechanism that operates in acidosis. The decrease in chloride excretion that accompanied the increase in organic acid excretion in Cooke's (5) studies is suggestive of such a mechanism. However, as we have seen, the term "alkalosis" is probably too restrictive to cover the basic intracellular mechanism regulating organic acid excretion.

In addition to this function, Shorr and his associates (24) emphasized that citrate excretion appears to play an important role in the solubilization of calcium in the urine and thus the prevention of renal calcinosis. Harrison and Harrison (7) in a different approach to the problem have ob- 
served in rats that the administration of Diamox ${ }^{\circledR}$ causes a profound inhibition of citrate excretion without a concomitant reduction in urinary calcium. Citrate can chelate calcium and in its absence calcium phosphate precipitates, with renal stones forming as a result. In line with the concept of citrate synthesis presented above, the action of Diamox ${ }^{\circledR}$ can be seen in terms of a reduction in intracellular citrate synthesis accompanying a reduced potassium, bicarbonate and $\mathrm{pH}$ in the tubule cells.

Another function of organic acid excretion appears to be related to the hormonal regulation of the menstrual cycle. Shorr, Bernheim and Taussky (25) have observed that citrate excretion is lowest during menstruation and rises in the immediate postmentrual period until, after a dip for a day or two in the midperiod, it rises to even higher rates that are sustained until the sharp decline just before the onset of the next menstruation. Evidence supporting the sex steroid control of these variations in citrate excretion derives from the fact that they can be produced at will by estradiol injection in amenorrheic females. Testosterone given to hypogonadal males also affects citrate excretion but in the opposite direction. The functional basis for these hormone-induced variations in citrate excretion is not at all understood. They may be the secondary result of a systemic change in acidbase balance or they may be the result of a steroid effect on tubular production of citrate. They occur without commensurate changes in plasma citrate levels.

The studies reported here have been mainly concerned with one of the substrates of the tricarboxylic acid cycle. To what extent these findings with malic acid relate to the general problem of organic acid excretion and its physiologic role cannot be stated with certainty at present. However, several important facts have emerged. First, this study has clearly demonstrated that at least one of the members of the tricarboxylic acid cycle can be secreted by the tubules in response to infusion of certain other members of the same cycle. Secondly, the succinoxidase enzyme system is apparently an important component of this mechanism. Thirdly, the curious and interesting fumarate "catalysis" of malate reabsorption has been described. This phenomenon suggests that elements of the cycle are involved in both the tubular secretion and reabsorption of malate.

Thus the general concept presents itself that the tricarboxylic acid cycle, usually considered as an oxidative mechanism in energy metabolism, functions also in the kidney in the synthesis, reabsorption and secretion of its own intermediates. This may be analogous to the way pyridoxal phosphate functions in amino acid transport (26) in a way quite separate from its role in intermediary metabolism of amino acids, or to the way adenosine triphosphate functions in the red cell membrane in phosphate transport (27) quite separately from its role in intracellular energy metabolism. Much additional work will be required before this hypothesis can stand or fall on the basis of solid observation.

\section{SUMMARY}

The mechanism of excretion of malic acid was studied in the dog during infusion of several tricarboxylic acid cycle intermediates including $l$-malic acid itself. With infusion of citrate, $\alpha$-ketoglutarate and succinate there was glomerular filtration and net tubular secretion of malate. With each of these substrates following infusion of the succinoxidase inhibitor, malonic acid, the net tubular secretion of malate completely disappeared and glomerular filtration with net reabsorption of malate was seen instead. Thus it appears that the tubules are capable of synthesizing malate from precursors in the tricarboxylic acid cycle and secreting it into the tubular urine. In contrast to these findings, the infusion of fumarate or $l$-malate leads only to malate filtration and reabsorption. Thus the tubules are capable of both secretion and reabsorption of malate under certain definite conditions. During $l$-malate infusion there was a definite "Tm" for malate reabsorption that averaged 4 to $8 \mathrm{mg}$. per minute. During fumarate infusion the capacity of the tubules to reabsorb malate was greatly increased. This phenomenon was shown to be the result of a "catalytic" effect of fumarate on malate reabsorption. The relation of these studies to the operation of the tricarboxylic acid cycle in the kidney and the whole problem of organic acid excretion was discussed. 


\section{ACKNOWLEDGMENTS}

The authors wish to thank Mr. Seraphim Woronkow for valuable technical assistance and Mr. John Pottschmidt who helped on some of the work as a summer research project while a medical student.

\section{REFERENCES}

1. Krebs, H. A., and Johnson, W. A. Role of citric acid in intermediate metabolism in animal tissues. Enzymologia 1937, 4, 148.

2. Nordmann, J., and Nordmann, R. Les acides du cycle tricarboxylique en chimie clinique. Clin. Chem. 1957, 3, 462.

3. Östberg, O. Studien über die Zitronensäureousscheidung der Menschenniere in normalen und pathologischen Zuständen. Skand. Arch. Physiol. 1931, 62, 81.

4. Evans, B. M., MacIntyre, I., MacPherson, C. R., and Milne, M. D. Alkalosis in sodium and potassium depletion (with special reference to organic acid excretion). Clin. Sci. 1957, 16, 53.

5. Cooke, R. E., Segar, W. E., Reed, C., Etzwiler, D. D., Vita, M., Brusilow, S., and Darrow, D. C. The role of potassium in the prevention of alkalosis. Amer. J. Med. 1954, 17, 180.

6. Melius, P., and Lipton, M. A. Organic acid excretion in experimental alkalosis. Fed. Proc. 1957, 16, 221.

7. Harrison, H. E., and Harrison, H. C. Inhibition of urine citrate excretion and production of renal calcinosis in the rat by acetazoleamide (Diamox (i)) administration. J. clin. Invest. 1955, 34, 1662.

8. Craig, J. W., Miller, M., Owens, J. E., and Woodward, H., Jr. Renal malic acid metabolism in vivo. Fed. Proc. 1953, 12, 29.

9. Braun, W., Whittaker, V. P., and Lotspeich, W. D. Renal excretion of phlorizin and phlorizin glucuronide. Amer. J. Physiol. 1957, 190, 563.

10. Hummel, J. P. The fluorometric determination of malic acid. J. biol. Chem. 1949, 180, 1225.

11. Umbreit, W. W., Burris, R. H., and Stauffer, J. F. Manometric Techniques and Related Methods for the Study of Tissue Metabolism. Minneapolis, Burgess Publishing Co., 1945, p. 116.

12. Natelson, S., Pincus, J. B., and Lugovoy, J. K. Microestimation of citric acid: A new colorimetric reaction for pentabromacetone. J. biol. Chem. $1948,175,745$.
13. Taggart, J. V. Protein binding of p-aminohippurate in human and dog plasma. Amer. J. Physiol. 1951, 167, 248.

14. Annau, E., Banga, I., Gözsy, B., Huszák, St., Laki, K., Straub, B., and Szent-Györgyi, A. Uber die Bedeutung der Fumarsäure für die tierische Gewebsatmung: Einleitung, Úbersicht methoden. Hoppe-Seylers Z. physiol. Chem. 1935, 236, 1.

15. Stare, F. J., and Baumann, C. A. The effect of fumarate on respiration. Proc. roy. Soc. B 1936, 121, 338.

16. Herrin, R. C., and Lardinois, C. C. Renal clearance of citrate in dogs. Fed. Proc. 1947, 6, 129.

17. Cohen, J. J. Simultaneous renal tubular reabsorption and utilization of metabolites by the dog kidney in vivo. The Physiologist 1958, 1, 9.

18. Krebs, H. A. The equilibrium constants of the fumarase and aconitase systems. Biochem. J. 1953, 54, 78.

19. Stern, J. R., Ochoa, S., and Lynen, F. Enzymatic synthesis of citric acid: V. Reaction of acetyl coenzyme A. J. biol. Chem. 1952, 198, 313.

20. Orten, J. M., and Smith, A. H. A study of certain metabolites and related compounds as precursors of endogenous citric acid. J. biol. Chem. 1937, 117, 555.

21. Krebs, H. A., Salvin, E., and Johnson, W. A. The formation of citric and $\alpha$-ketoglutaric acids in the mammalian body. Biochem. J. 1938, 32, 113.

22. Milne, M. D., Scribner, B. H., and Crawford, M. A. Non-ionic diffusion and the excretion of weak acids and bases. Amer. J. Med. 1958, 24, 709.

23. Anderson, H. M., and Mudge, G. H. The effect of potassium on intracellular bicarbonate in slices of kidney cortex. J. clin. Invest. 1955, 34, 1691.

24. Shorr, E., Almy, T. P., Sloan, M. H., Taussky, H., and Toscani, V. The relation between the urinary excretion of citric acid and calcium: Its implications for urinary calcium stone formation. Science 1942, 96, 587.

25. Shorr, E., Bernheim, A. R., and Taussky, H. The relation of urinary citric acid excretion to the menstrual cycle and the steroidal reproductive hormones. Science 1942, 95, 606.

26. Christensen, H. N. Mode of transport of amino acids into cells in Amino Acid Metabolism. Baltimore, Johns Hopkins, 1955, p. 63.

27. Gourley, D. R. H. The role of adenosine triphosphate in the transport of phosphate in the human erythrocyte. Arch. Biochem. 1952, 40, 1. 